\title{
Effects of Abscisic Acid on Growth and Cadmium Accumulation of Pea Seedlings
}

\author{
Qiyu Lu ${ }^{1, a}$, Guochao Sun ${ }^{2, b}$, Ji Liü ${ }^{3, c}$ and Yi Tang ${ }^{2, d *}$ \\ ${ }^{1}$ College of Horticulture, Sichuan Agricultural University, Chengdu, Sichuan, China \\ ${ }^{2}$ Institute of Pomology and Olericulture, Sichuan Agricultural University, Chengdu, Sichuan, China \\ ${ }^{3}$ Chengdu Academy of Agriculture and Forestry, Chengdu, Sichuan, China \\ a1142750379@qq.com, b6183090@qq.com, c34905418@qq.com, d95459425@qq.com \\ ${ }^{*}$ Corresponding author. Qiyu Lu and Guochao Sun contributed equally to this work.
}

Keywords: Abscisic acid (ABA); Pea seedlings; Cadmium; Growth

\begin{abstract}
The effects of soaking seedlings of four abscisic acid (ABA) concentrations $(0,1,5,10$, and $20 \mu \mathrm{mol} / \mathrm{L}$ ) on the growth and cadmium $(\mathrm{Cd})$ accumulation of pea seedlings were studied by the pot experiment. The results showed that, compared with the control, the roots, stems, leaves, and shoots biomasses of pea seedlings were increased by soaking with ABA. Compared with the control, the water content in the roots, stems and shoots of pea seedlings was increased, and the concentration of $5 \mu \mathrm{mol} / \mathrm{L}$ ABA was the best. The contents of $\mathrm{Cd}$ in various parts of pea seedlings treated with 5, 10, and $20 \mu \mathrm{mol} / \mathrm{L}$ ABA all decreased. With the increase of ABA concentration, the $\mathrm{Cd}$ content of pea seedlings gradually decreased. Therefore, a certain concentration of ABA soaking treatment can improve the growth of pea stress pea seedlings and reduce the accumulation of $\mathrm{Cd}$.
\end{abstract}

\section{Introduction}

In recent years, with the development of industry, soil heavy metal pollution has become increasingly serious [1]. Cadmium $(\mathrm{Cd})$ is a non-essential trace element in plants and has a strong poisoning effect on plants. The phytohormone abscisic acid (ABA), as an important hormone for plants to respond to stress, plays an important regulatory role in plant growth and development [2]. ABA can reduce the transport capacity of $\mathrm{Cd}$ to shoots parts of non-heading Chinese cabbage (Brassica campestrisssp. chinensis L.) and reduce the shoots $\mathrm{Cd}$ content of non-heading Chinese cabbage [3]. Exogenous ABA can effectively reduce the Cd content in rice may be due to ABA can reduce the transport of $\mathrm{Cd}$ by reducing the transpiration rate of plants [4]. Vegetables are one of the indispensable foods in life, and the accumulation of heavy metals in vegetables can endanger human health and life safety through the food chain [5]. Pea is a leguminous vegetable plant that has high nutritional value and anti-cancer and anti-cancer effects. It is widely cultivated throughout the country [6]. However, Cd pollution in vegetable fields in recent years directly affects the safe production of peas [7-8]. Therefore, this experiment used ABA to soak seeds to study its effect on the growth and accumulation of pea seedlings, in order to screen out the concentration of ABA which can reduce the accumulation of pea seedlings and enhance the seedling production efficiency, and provide reference for safe production of peas.

\section{Materials and Methods}

Materials Collection. Pea variety: Cheng Wan 8 (strong growth potential, multiple branches, good stability, and wide adaptability), purchased in Wenjiang District, Chengdu. The fluvo-aquic soil were collected from the farmland was not contaminated by heavy metals at Wenjiang, Chengdu City, Sichuan Province, China.

Experimental Design. The soil was air-dried and passed through a $6.72-\mathrm{mm}$ sieve. $0.5 \mathrm{~kg}$ air-dried soil was weighed into each plastic pot $(15 \mathrm{~cm}$ high, $11 \mathrm{~cm}$ in diameter), soaking uniformly by 10 $\mathrm{mg} / \mathrm{kg} \mathrm{Cd}$ (in the form of $\mathrm{CdCl}_{2} \cdot 2.5 \mathrm{H}_{2} \mathrm{O}$ ) solution. Keep the soil moist and place it for 30 days. 
Tumble the soil to make it evenly mixed. Pea seeds were soaked in 5 concentrations $(0,1,5,10$, and $20 \mu \mathrm{mol} / \mathrm{L}$ ) of ABA for 24 hours, and each treatment was repeated three times. The pea seeds were planted in PVC pots that had been filled with soil and 8 pots were planted in each pot. The planting depth was shallow. Keep moist, place in the culture room, keep the temperature of the culture room around $24^{\circ} \mathrm{C}$. After emergence, the PVC pots were moved to shelters in the shelters. Each pot kept 5 seedlings with consistent growth, and watered in time to keep the soil moist. After $40 \mathrm{~d}$ cultivation, pea seedlings were harvested and biomass and moisture content were measured using conventional methods. The roots and shoots were then collected, washed clean with tap water, and rinsed three times with deionized water before being dried and ground separately. Samples were fixed at $110^{\circ} \mathrm{C}$ for $15 \mathrm{~min}$ and dried at $75^{\circ} \mathrm{C}$ to a constant weight before being crushed and sieved through a 100-mesh screen for further analysis. The $\mathrm{Cd}$ content of roots and shoots was determined using an iCAP 6300 inductively coupled plasma spectrometer [9].

Statistical Analyses. Statistical analyses were performed using SPSS 13.0 statistical software (IBM, Chicago, IL, USA). Data were analyzed by one-way analysis of variance with Duncan's multiple range test.

\section{Results and Discussion}

Effects of ABA Treatments with Different Concentrations on the Biomass of Pea Seedlings. As shown in Table 1, compared with the control, after soaking with ABA, the root and shoots biomass and root volume of pea seedlings all significantly $(p<0.05)$ increased. The fresh weight of roots, stems, leaves and shoots and root volume increased at first and then decreased with the increase of $\mathrm{ABA}$ concentration, and reached the maximum at ABA concentration of $5 \mu \mathrm{mol} / \mathrm{L}$, which was higher than that of their respective controls. It increased by $27.50 \%(p<0.05), 22.18 \%(p<0.05)$, $15.36 \%(p<0.05), 15.99 \%(p<0.05)$, and 32.07\% $(p<0.05)$. Thus, soaking seeds with ABA could increase the fresh weight and root volume of pea seedlings, and the effect of ABA concentration was $5 \mu \mathrm{mol} / \mathrm{L}$.

Table 1 Effects of ABA treatments with different concentrations on the biomass of pea seedlings

\begin{tabular}{|c|c|c|c|c|c|}
\hline $\begin{array}{c}\text { ABA } \\
\text { concentration } \\
(\mu \mathrm{mol} / \mathrm{L})\end{array}$ & $\begin{array}{c}\text { Root } \\
(\mathrm{g} / \text { plant })\end{array}$ & $\begin{array}{c}\text { Stem } \\
(\mathrm{g} / \mathrm{plant})\end{array}$ & $\begin{array}{c}\text { Leaves } \\
(\mathrm{g} / \mathrm{plant})\end{array}$ & $\begin{array}{c}\text { Shoots } \\
\text { (g/plant })\end{array}$ & $\begin{array}{c}\text { Root volume } \\
(\mathrm{ml} / \mathrm{plant})\end{array}$ \\
\hline 0 & $10.177 \pm 0.204 \mathrm{~d}$ & $6.911 \pm 0.228 \mathrm{c}$ & $8.466 \pm 0.202 \mathrm{~b}$ & $15.70 \pm 0.58 \mathrm{~b}$ & $10.6 \pm 0.3 \mathrm{~b}$ \\
\hline 1 & $12.182 \pm 0.153 \mathrm{~b}$ & $7.546 \pm 0.313 \mathrm{~b}$ & $8.964 \pm 0.222 \mathrm{~b}$ & $16.33 \pm 0.72 \mathrm{~b}$ & $13.5 \pm 0.4 \mathrm{a}$ \\
\hline 5 & $12.976 \pm 0.252 \mathrm{a}$ & $8.444 \pm 0.119 \mathrm{a}$ & $9.766 \pm 0.358 \mathrm{a}$ & $18.21 \pm 0.55 \mathrm{a}$ & $14.0 \pm 0.4 \mathrm{a}$ \\
\hline 10 & $12.792 \pm 0.132 \mathrm{a}$ & $7.252 \pm 0.199 \mathrm{bc}$ & $9.035 \pm 0.239 \mathrm{~b}$ & $16.29 \pm 0.31 \mathrm{~b}$ & $13.8 \pm 0.5 \mathrm{a}$ \\
\hline 20 & $10.866 \pm 0.263 \mathrm{c}$ & $7.237 \pm 0.227 \mathrm{bc}$ & $8.782 \pm 0.246 \mathrm{~b}$ & $15.88 \pm 0.41 \mathrm{~b}$ & $11.0 \pm 0.2 \mathrm{~b}$ \\
\hline
\end{tabular}

Values are means \pm standard errors. Means with the same letter within each column are not significantly different at $p<0.05$.

Effects of ABA Treatments with Different Concentrations on Water Content of Pea Seedlings. After soaking with different concentrations of ABA, the water contents in roots, stems and shoots of pea seedlings improved compared with the control (Table 2). Compared with the control, there was no significant difference in leaf water content of pea seedlings soaking with $\mathrm{ABA}(p<0.05)$. The water content of roots, stems and shoots reached the maximum when the concentration of ABA was $5 \mu \mathrm{mol} / \mathrm{L}$, which was $1.22 \%(p<0.05), 1.73 \%(p<0.05)$ and $0.77 \%(p<0.05)$ higher than that of their respective controls. Therefore, soaking seeds with ABA could improve the water content of all parts of pea seedlings, and the ABA concentration of $5 \mu \mathrm{mol} / \mathrm{L}$ was the best. 
Table 2 Effects of ABA treatments with different concentrations on water content of pea seedlings

\begin{tabular}{|c|c|c|c|c|}
\hline $\begin{array}{c}\text { ABA } \\
\text { concentration } \\
(\mu \mathrm{mol} / \mathrm{L})\end{array}$ & $\begin{array}{c}\text { Roots } \\
(\%)\end{array}$ & $\begin{array}{c}\text { Stems } \\
(\%)\end{array}$ & $\begin{array}{c}\text { Leaves } \\
(\%)\end{array}$ & $\begin{array}{c}\text { Shoots } \\
(\%)\end{array}$ \\
\hline 0 & $92.88 \pm 0.473 \mathrm{c}$ & $87.34 \pm 0.298 \mathrm{~b}$ & $86.90 \pm 0.297 \mathrm{a}$ & $87.24 \pm 0.195 \mathrm{~b}$ \\
\hline 1 & $93.75 \pm 0.404 \mathrm{ab}$ & $88.31 \pm 0.278 \mathrm{a}$ & $87.02 \pm 0.202 \mathrm{a}$ & $87.78 \pm 0.263 \mathrm{ab}$ \\
\hline 5 & $94.01 \pm 0.196 \mathrm{a}$ & $88.85 \pm 0.386 \mathrm{a}$ & $87.46 \pm 0.277 \mathrm{a}$ & $87.91 \pm 0.274 \mathrm{a}$ \\
\hline 10 & $93.42 \pm 0.281 \mathrm{abc}$ & $88.79 \pm 0.451 \mathrm{a}$ & $87.16 \pm 0.169 \mathrm{a}$ & $87.82 \pm 0.281 \mathrm{ab}$ \\
\hline 20 & $92.96 \pm 0.383 \mathrm{bc}$ & $88.49 \pm 0.226 \mathrm{a}$ & $87.00 \pm 0.184 \mathrm{a}$ & $87.62 \pm 0.269 \mathrm{ab}$ \\
\hline
\end{tabular}

Values are means \pm standard errors. Means with the same letter within each column are not significantly different at $p<0.05$.

Effects of ABA Treatments with Different Concentrations on Cd Content in Pea Seedlings. As shown in table 3, compared with the control, the Cd content in the pea seedlings soaked in the concentration range of 5, 10, and $20 \mu \mathrm{mol} / \mathrm{L}$ ABA decreased significantly. In the range of ABA concentrations of 5,10 , and $20 \mu \mathrm{mol} / \mathrm{L}$, when the concentration of ABA gradually increased, the $\mathrm{Cd}$ content of pea seedlings gradually decreased. Compared with the control, the $\mathrm{Cd}$ content in roots, stems, leaves, and shoots of pea seedlings decreased by $26.47 \%(p<0.05), 3.01 \%(p<0.05)$, $34.65 \%(p<0.05)$, and $25.19 \%(p<0.05)$, respectively, after soaking with $5 \mu \mathrm{mol} / \mathrm{L}$ ABA. After soaking with $10 \mu \mathrm{mol} / \mathrm{L} \mathrm{ABA}$, the Cd content in the roots, stems, leaves and shoots of pea seedlings was reduced by $31.29 \%(p<0.05), 22.56 \%(p<0.05), 42.54 \%(p<0.05)$, and $57.47 \%(p<0.05)$, respectively, compared with the control. Compared with the control, the Cd content in roots, stems, leaves, and shoots of pea seedlings decreased by 56.48\% $(p<0.05), 44.36 \%(p<0.05), 69.30 \%(p$ $<0.05)$, and $61.80 \%(p<0.05)$, respectively, after soaking with $20 \mu \mathrm{mol} / \mathrm{L}$ ABA. Therefore, ABA in a certain concentration range can reduce the $\mathrm{Cd}$ content of pea seedlings.

Table 3 Effects of ABA treatments with different concentrations on Cd content of pea seedlings

\begin{tabular}{|c|c|c|c|c|}
\hline $\begin{array}{c}\text { ABA } \\
\text { concentration } \\
(\mu \mathrm{mol} / \mathrm{L})\end{array}$ & $\begin{array}{c}\text { Roots } \\
(\mathrm{mg} / \mathrm{kg})\end{array}$ & $\begin{array}{c}\text { Stems } \\
(\mathrm{mg} / \mathrm{kg})\end{array}$ & $\begin{array}{c}\text { Leaves } \\
(\mathrm{mg} / \mathrm{kg})\end{array}$ & $\begin{array}{c}\text { Shoots } \\
(\mathrm{mg} / \mathrm{kg})\end{array}$ \\
\hline 0 & $105.79 \pm 3.566 \mathrm{a}$ & $1.33 \pm 0.019 \mathrm{~b}$ & $2.28 \pm 0.076 \mathrm{a}$ & $1.877 \pm 0.028 \mathrm{a}$ \\
\hline 1 & $109.05 \pm 3.883 \mathrm{a}$ & $1.41 \pm 0.012 \mathrm{a}$ & $2.32 \pm 0.052 \mathrm{a}$ & $1.922 \pm 0.039 \mathrm{a}$ \\
\hline 5 & $77.79 \pm 2.755 \mathrm{~b}$ & $1.29 \pm 0.042 \mathrm{~b}$ & $1.49 \pm 0.053 \mathrm{~b}$ & $1.404 \pm 0.024 \mathrm{~b}$ \\
\hline 10 & $72.69 \pm 1.914 \mathrm{~b}$ & $1.03 \pm 0.049 \mathrm{c}$ & $1.31 \pm 0.022 \mathrm{c}$ & $1.192 \pm 0.022 \mathrm{c}$ \\
\hline 20 & $46.04 \pm 0.625 \mathrm{c}$ & $0.74 \pm 0.003 \mathrm{~d}$ & $0.70 \pm 0.003 \mathrm{~d}$ & $0.717 \pm 0.006 \mathrm{~d}$ \\
\hline
\end{tabular}

Values are means \pm standard errors. Means with the same letter within each column are not significantly different at $p<0.05$.

\section{Conclusions}

After soaking with different concentrations of ABA, the biomass and root volume of roots, stems, leaves, and shoots of pea seedlings under Cd stress increased. The water content of the roots, stems and shoots of pea seedlings was increased compared to the control, and the effect was best when the concentration of ABA reached $5 \mu \mathrm{mol} / \mathrm{L}$. The higher concentration of ABA soaking treatment can reduce the $\mathrm{Cd}$ content of pea seedlings. Therefore, a certain concentration of $\mathrm{ABA}$ soaking 
treatment can improve and improve the growth of pea stress pea seedlings, reduce the accumulation of Cd.

\section{Acknowledgements}

This work was financially supported by the Application Infrastructure Project of Science and Technology Department of Sichuan Province (2016JY0258).

\section{References}

[1] J. Yang, Y.L. Zhao, Q. Zhen and J. Zhang: Journal of Ecology and Rural Environment Vol. 30(2014), p. 234.

[2] L.Y. Zhao, H.W. Li and Y.W. Song: Journal of Henan Normal University (Natural Science) Vol. 38(2010), p. 127.

[3] H.S. Qian, Y.H. Chen, G.P. Wang and Z.G. Shen: Journal of Nanjing Agricultural University (Natural Science) Vol. 31(2008), p. 61.

[4] Y.T. Hsu and C.H. Kao: Plant Cell \& Environment Vol. 26(2003), p. 867.

[5] S.H. Li, Z.G. Wen, Y.R. Chen and Y.H. Chen: Jiangsu Agricultural Sciences Vol. 44(2016), p. 231.

[6] Y.L. Cai, Y.J. Li, H. Liu, Y. Liang, H. Zhang, H. Bai, J. Gong and S.F. Ni: Ningxia Journal of Agri. and Fores. Sci.\& Tech Vol. 54(2013), p. 71.

[7] Q.L. Zhang, X.Z.Shi, B. Huang, D.S. Yu, H.J. Wang, B Karin and O Ingrid: Soils Vol. 37(2005), p. 41.

[8] J.Q. Song, Q. Zhu, X.S.Jiang, H.Y.Zhao, Y.H. Liang, Y.X. Luo, Q. Wang and L.L. Zhao: Acta Pedologica Sinica Vol. 54(2017), p. 81.

[9] S.D. Bao: Analysis of soil agrochemical (third edition) (China Agriculture Press, Beijing, China 2000). 